\title{
Profiles of New LIS Graduates - Current Librarians
}

For Partnership's $10^{\text {th }}$ anniversary issue, we're looking ahead to the future of LIS by talking to new and new-ish graduates. These three librarians have graduated recently and now have some experience on the job.

Meet our profiled librarians:

- Elizabeth Blackall, Community Librarian, Customer and Extension Services, Hamilton Public Library

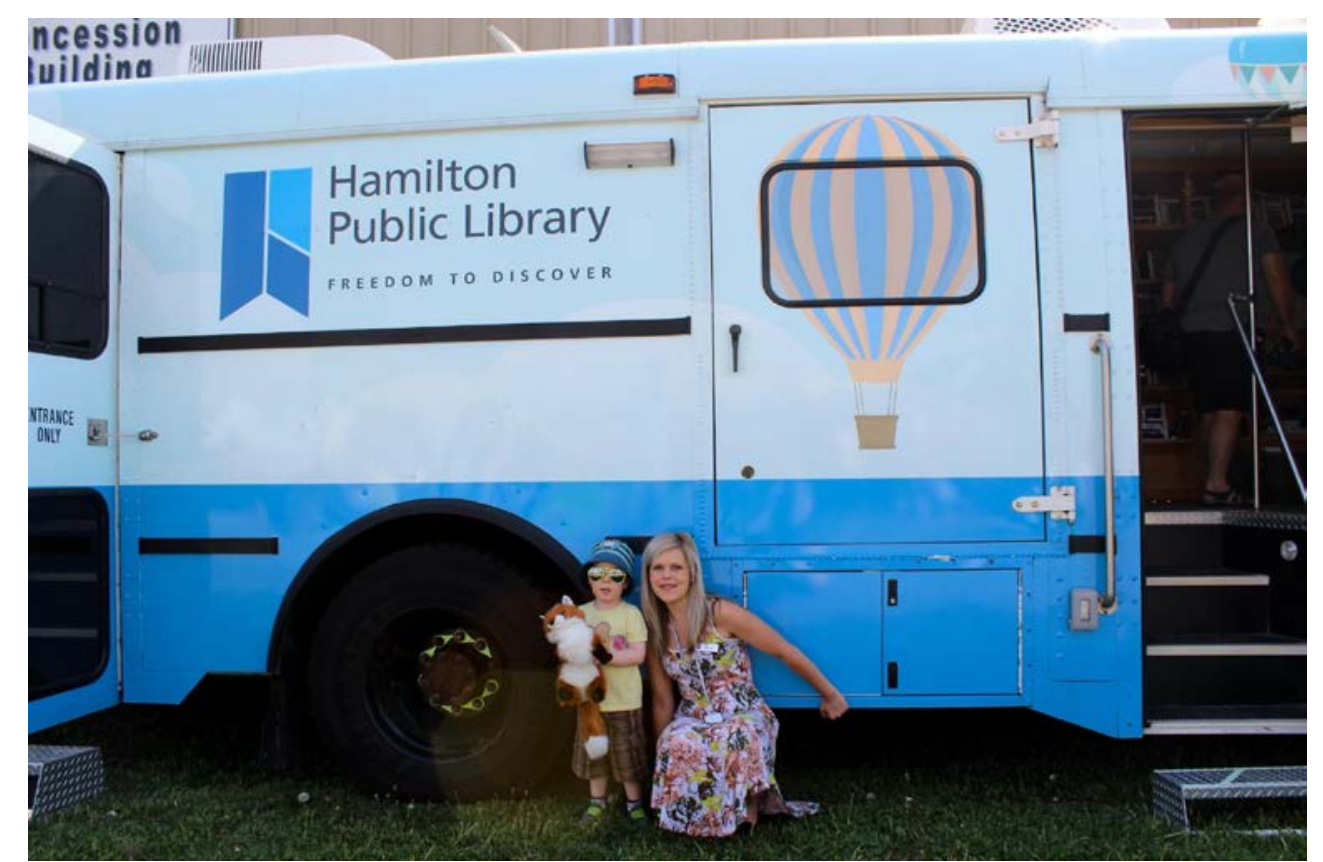

Figure 1. Elizabeth Blackall, Community Librarian, Customer and Extension Services, Hamilton Public Library

- Ashley Booth, Medical Librarian, Saskatoon Health Region Medical Library 
- Ali Versluis, Research Enterprise and Scholarly Communication Librarian, University of Guelph

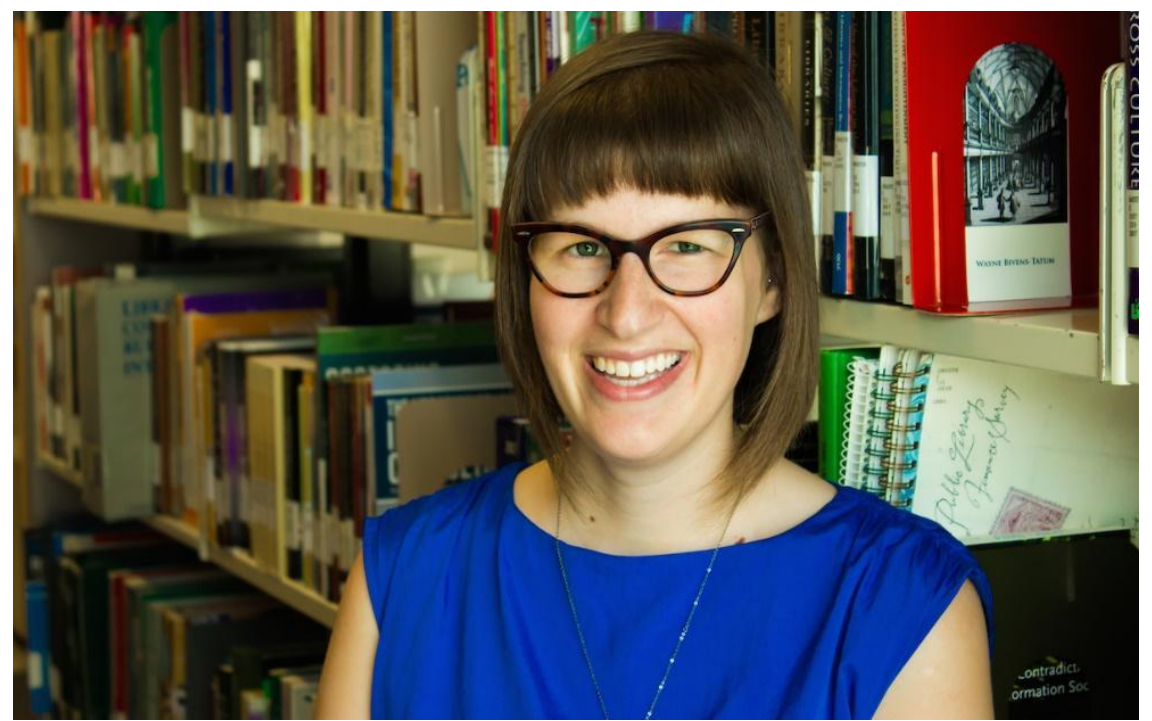

Figure 2. Ali Versluis, Research Enterprise and Scholarly Communication Librarian, University of Guelph

We asked them about their place in librarianship, their library inspirations, the future of the profession, and their lives outside of LIS.

\section{Tell us a little about your early background.}

Ashley: I grew up in small-town Saskatchewan, where the population is mostly tumbleweeds masquerading as people. It was quite lovely-and I credit much of my love of literacy, community, and everything library, to my small-town little library that could. It was open a grand total of maybe 10 hours a week, and you bet I was there every hour of every week, harassing the librarian to let me play games on the computer and trolling Harry Potter message boards. Yes, I was that kid. Trust me, things got a little better and brighter for me.

Elizabeth: I grew up in London, Ontario, where I also attended Western University for an undergraduate degree in English Literature and later for Education.

\section{What (or who) inspired you to pursue a career in libraries?}

Ali: Two people: my friend Kristin Nicholson, and Lorraine Janzen Kooistra. Although I knew you had to complete additional schooling to become a librarian (I admit, I totally said "you need another degree for that?" the first time I heard about library school), I hadn't really ever given it much thought until I went on exchange at the University of PEI in my third year of undergrad. It was there that I met Kristin, a student who worked at Robertson Library. Being curious about the type of work library staff did, I asked lots of questions. Her answers were always really positive: variety of tasks, great colleagues, making a difference in the lives of students and faculty. 
When I returned to Ryerson, I was lucky enough to connect with Lorraine. She immediately took an interest in me, so after telling her I thought l'd like to be a librarian, she offered me a research assistant position with a digital humanities project. Although not affiliated with the library, the fact that this project was starting to really get underway meant that there was lots of collaboration and discussion between the library and the project's Principal Investigators. This gave me a glimpse into aspects of librarianship I previously knew nothing about: fostering local and international collaborations, working with books and rare materials, wrangling metadata, doing markup, and teaching. It was then that I began to truly understand the myriad of things librarians could do and thought "Yeah, I definitely want to do this."

Elizabeth: I originally set out to be a high school teacher. In order to gain experience, I volunteered (and later worked) for St. Joseph's Hospital and the Third Age Outreach program there, teaching computer lessons to older adults. I loved working with seniors and the experience helped me realize the important benefits of digital literacy and lifelong learning. Librarianship is the perfect profession for me because I get to work with a diverse range of people and every day is different.

\section{What has you most excited about the future of libraries and information science?}

Ali: The existence of critical librarianship. As Ryan Randall explains in his Hack Library School post, this approach is largely understood as the application of critical perspectives to analyze the work we do in libraries and archives. While some people understand this as actually applying critical theory, others conceive of it more generally as being critical of the discourses, roles, and ideas perpetuated in information based work. Critical librarianship, or critlib, is the subject of a popular hashtag (\#critlib), a number of different conferences and workshops, and a handful of journal articles and (at least) one book.

I think that because information professionals are often affiliated with non-profit organizations, we tend to forget-or in some cases, are unaware-that our existence is predicated on various power structures. Critical librarianship does the good work of interrogating these power structures in the hopes of disrupting them. Topics of discussion focus on labour solidarity, emotional labour, hiring practices, LC classification, LIS education, and microaggressions, to name a few. These are conversations that have been missing from the mainstream LIS discourse for far too long, so now we find them further complicating our basic assumptions about the work we do. This is a good thing though-it's necessary to becoming more compassionate, empathetic professionals that can better advocate for our users and ourselves.

I hope that one day critlib becomes less niche and loses its 'critical' modifier. This type of work should just be part of librarianship.

Elizabeth: People are investing more in their communities. There is recognition that we can make a real difference in the places where we live-in Hamilton there are so many exciting non-profit organizations, community groups, local initiatives, and small 
businesses. They all have a sense of purpose and support each other. With this trend I see such potential for the library to play an increasingly valuable role as a community hub where people and groups come together to share resources, information, and ideas.

The sharing economy is another exciting movement I see(and, while the term is relatively new, public libraries have been doing it for years!). As people look to consume less and borrow more, public libraries will continue to expand and diversify their physical and digital collections in order to meet the demands of patrons.

Ashley: Information literacy and all the baggage along with it. Literacy has gotten infinitely more complicated-as we're all aware. Just trying to understand and work with how this suddenly widening gap is something we have to deal with-not just with our patients, but with our staff too (which are often highly educated and whip-smart, but egads, sometimes they've fallen in that technology literacy gap and can't get up!) and how this scary quagmire of low health and technological literacy really impacts everything we do.

\section{What was your most interesting or most valuable assignment during your time at school?}

Elizabeth: I was selected for two co-op positions during my time at school. My first placement was with the Forest of Reading at the Ontario Library Association. I helped coordinate communications and event planning for the Forest of Reading festivals in Toronto and North Bay. My second placement was at Hamilton Public Library, creating storytime outlines and staff resources for the Youth Services department. Not only did I learn a lot about public libraries in both positions, I also made valuable connections with some great people. Without these experiences I know I wouldn't be in the role I am today.

Ashley: Honestly, probably my cataloguing courses, because I learned very solidly that I was never destined to be a cataloguer, or an archivist.

Ali: I took a few courses in critical, literary, and cultural theory during my undergrad at Ryerson. It's an understatement to say that these courses were influential-they completely upended how I think, how I see the world, and how I conceptualize things like gender, race, sexuality, and class. At the time, the ideas articulated in those courses unsettled me to my core and made me deeply uncomfortable. Now I realize how significant-even crucial-feeling that discomfort is in order to better understand the world around you.

\section{If you could ask one question of someone 5, 10, or 25 years along in their career, what would you ask?}

Ali: 5 years: "How can the profession better support you and your work?"

10 years: "Where do you see the profession going?" 
25 years: "When are you retiring?" Just kidding! I'd probably ask something like "Is there anything you regret or would have done differently?"

Elizabeth: I would want to ask someone in a director or CEO position what experiences they found most beneficial in helping them to progress their careers. What did they enjoy most about working at each different level? What positions did they find the most rewarding? What challenges did they take on that taught them the most?

\section{Are you involved in extracurricular activities or volunteer work related to libraries or information science?}

Ali: I've been involved in a smattering of things since I finished library school. I cochaired the Access Library Technology Conference, worked on the Advocacy and Communications Committees for CAPAL (Canadian Association of Professional Academic Librarians), and served on the Assessment and Accessibility Communities. Right now my big projects are helping with Code4LibNorth, co-organizing a New Librarians Symposium for June 2016, and getting settled into my brand new role as comoderator of the Ontario Council of University Libraries (OCUL) Publishing and Hosting Community. I'm also doing a lot of mentoring (assisting with cover letters, interview prep, and general morale boosting) with new and recent grads, which I find super rewarding. As a student, I was supremely lucky to have a large network of academic librarians who gave me perspective on culture, hiring norms, and expectations, so I'm jazzed to be in a position where I can help others.

Elizabeth: Before library school I volunteered teaching computer lessons to senior citizens, and I have also volunteered in high schools helping students complete their coursework. Volunteering is one of the best ways l've found to meet new people and learn new things. Hamilton is a new city for me, but getting involved in my community makes it feel like home. When I volunteer I also feel like I'm developing skills that make me a better librarian. For me, l've found it increases my empathy, pushes me to try new things, and develops my leadership skills. It's also great for relieving stress after a long day at work!

I play violin in the Dundas Valley Community Orchestra, volunteer with The Equestrian Association for the Disabled, and I just got back from a service trip to Guatemala with Librarians Without Borders (LWB).

\section{What has been the biggest challenge of your library career so far?}

Ashley: Trying to jump ahead with innovation and change in a giant organization is a challenge. Anyone working in a health region or large system knows "these feels" of trying to convince your patrons and staff that change is good. We need to evolve as our patients' and staff's needs evolve, and that's a very scary word for people. Changing, evolving, innovating: RUN.

Elizabeth: As a young professional there's so much for me to learn about management and leadership_-l'm always trying to push myself to seek out learning experiences and 
try new things. Right now I'm writing my first conference proposals—it's a little outside my comfort zone, but I recognize that contributing to the library community as a whole is an important part of professional development.

My organization also offers many opportunities to build management skills and experience through committee roles and training. I've also been fortunate to have great mentors since the beginning of my career-though we work in a competitive job market, I think that librarianship is a supportive and welcoming profession.

Ali: Being a new librarian. Besides the obvious implications this has on precarity, possessing this status has two repercussions in the working world: you're often not taken seriously, or you're expected to save the library/profession/world/fill in the blank for some important project.

This is obviously problematic on a number of levels. Not only does it negate someone's life experience/creativity/hustle, but also neglects the fiefdom/power structures that tend to exist within libraries, where people can be territorial and, in some cases, even outright hostile to others, when they feel their role or responsibilities are threatened.

I would like to see us better support our students, new grads, and early career professionals. That can take on many forms: serving as a mentor, giving them projects that are well defined, achievable, and supported by others (both in mentality and in workload), and even just touching base and seeing how they're doing. That empathy part is what I want to emphasize. I think once we're settled in-whether that be to a role, an institution, or in our career trajectory-we tend to forget what it was like at the beginning, when we were precariously employed, wracked with insecurity, having to constantly prove ourselves, and essentially experiencing imposter syndrome all the time. We don't talk enough about mental health and self-care in LIS, and I would like to see that change.

\section{What do you do for fun?}

Ali: Travel (usually to urban centres in the US and Canada), collect notecards and stationery (I'm a prolific letter writer, but I always seem to accrue it faster than I use it up), and drink craft beer. I love plants, so one of my recent hobbies is buying them and trying to keep them alive-I have about a 50/50 average at this point.

Ashley: Painting, eating sushi, taking long strolls through my Netflix queue.

Elizabeth: I love spending time outdoors-on my days off you'll probably find me out exploring some trails, riding my bike, or learning how to garden. 


\section{Do you have a website or any social media accounts you would like us to link to?}

Ashley: @shrmedlib on Twitter.

Ali: I tweet half-formed thoughts and ideas at @aliversluis. I keep it locked because well, precarity.

\section{Is there anything else you'd like to mention that might interest Partnership's readers?}

Elizabeth: The Miguel Angel Asturias Academy is the non-profit school I volunteered at with LWB.

The partnership between LWB and Michael Angel Asturias Academy is a beautiful example of how organizations can benefit each other. The students and young professionals who travel to Guatemala each year learn so much, and LWB is able to help the small school library with providing fresh resources and by completing various projects. This year LWB donated and catalogued close to 200 Spanish books, provided professional development seminars for teachers, and ran a really fun Library Day program for all of the students. 